\title{
A Mutualism Between Unattached Coralline Algae and Seagrasses Prevents Overgrazing by Sea Turtles
}

\author{
Luuk Leemans, ${ }^{3 *}$ Isis Martínez, ${ }^{2}$ Tjisse van der Heide, ${ }^{1}$ \\ Marieke M. van Katwijk, ${ }^{3}$ and Brigitta I.van Tussenbroek ${ }^{2,3}$
}

\begin{abstract}
${ }^{1}$ Department of Aquatic Ecology and Environmental Biology, Institute for Water and Wetland Research, Radboud University, Nijmegen, The Netherlands; ${ }^{2}$ Unidad Académica Sistemas Arrecifales-Puerto Morelos, Instituto de Ciencias del Mar y Limnología, Universidad Nacional Autónoma de México, Puerto Morelos, Quintana Roo, Mexico; ${ }^{3}$ Department of Aquatic Ecology and Environmental Biology, Institute for Water and Wetland Research, Radboud University, Nijmegen, The Netherlands
\end{abstract}

\begin{abstract}
Seagrass meadows are threatened biodiversity hot spots that provide essential ecosystem services. Green sea turtles may overgraze meadows, further enhancing seagrass decline. However, we observed an unexpected, remarkable recovery of seagrasses in a previously overgrazed meadow with abundant unattached branched coralline algae, suggesting that turtle grazing had ceased. We hypothesize that this recovery is due to an effective grazing-protection mutualism, in which the spiny coralline algae structures protect the seagrass meadows from overgrazing, while the seagrasses protect the algae from removal by currents and waves. Removing coralline algae from recovered seagrass plots allowed the turtles to resume grazing, while addition of coralline algae to grazed plots caused cessation of grazing. Coralline algae that were placed on bare sand were quickly displaced by wave action, whereas those placed in grazed or ungrazed sea-
\end{abstract}

Received 28 August 2019; accepted 20 January 2020;

published online 18 February 2020

Electronic supplementary material: The online version of this article (https://doi.org/10.1007/s10021-020-00492-w) contains supplementary material, which is available to authorized users.

Author contributions BIT conceived the idea for the experiments; LL and BIT designed the methodology; MMK, LL, IM and BIT collected the data; TH, LL and BIT analyzed the data; LL led the writing of the manuscript; and TH, MMK and BIT supervised the writing of the manuscript. All authors contributed critically to the drafts and gave final approval for publication.

*Corresponding author; e-mail: 1.leemans@science.ru.nl grass remained. Our experiments demonstrate a grazing-protection mutualism, which likely explains the witnessed recovery of an overgrazed seagrass meadow. To our knowledge, this is the first account of a plant-plant grazing-protection mutualism in an aquatic environment. Our findings show that grazing-protection mutualisms can be vital for the maintenance and recovery of ecosystems shaped by habitat-structuring foundation species, and highlight the importance of mutualisms in coastal ecosystems. As seagrasses, sea turtles and coralline algae share habitats along tropical shores worldwide, the mutualism may be a global phenomenon. Overgrazing is expected to increase, and this mutualism adds a new perspective to the conservation and restoration of these valuable ecosystems.

Key words: seagrass; coralline algae; sea turtles; protection mutualism; overgrazing; coastal ecosystems; Thalassia testudinum; Neogoniolithon; plantplant mutualism.

\section{HighLIGHTS}

- A plant-plant mutualism protects seagrass meadows from overgrazing by green turtles. 
- Branched coralline algae discourage turtle grazing, seagrass shields algae from waves.

- Seagrasses, sea turtles and coralline algae cooccur globally.

\section{INTRODUCTION}

Seagrass meadows are essential ecological components of coastal zones due to their high productivity, sediment trapping and stabilization capacity, and provision of habitat or food to fauna, including fish, birds, invertebrates and iconic species such as dugong, manatee and green turtle (Hemminga and Duarte 2000; Waycott and others 2009). A growing number of studies points at the importance of trophic and non-trophic interaction networks in mediating seagrass ecosystem functioning. For example, Hughes and others (2013) showed how sea otters can mitigate negative effects of nutrient loading by preying on crabs that feed on grazers which control algal epiphytes on seagrasses. Another example is the three-way interaction where sulfide-oxidizing bacteria in the gills of lucinid bivalves protect seagrasses from sulfide toxicity in organic matter-rich seagrass sediments (van der Heide and others 2012).

In interaction networks, benefits from one species to the other are often mutual. Mutualisms are important determinants of functioning and community structure of ecosystems (Stachowicz 2001; Bruno and others 2003; Hay and others 2004; Toby Kiers and others 2010). Protection mutualism is a specific type of mutualism in which a mutualist defends its partner against natural enemies. A wellknown example of a protection mutualism that reduces grazing is the interaction between Cecropia trees and Azteca ants in the jungles of Central and South America. The trees provide the ants with nesting space and food packages, and in return the ants protect the trees by trimming competing vines and attacking herbivores (Janzen 1969; Schupp 1986). Although seagrasses engage in mutualistic interactions (van der Heide and others 2012; de Fouw and others 2016), there is currently no account of any documented plant-plant grazingprotection mutualisms in seagrass meadows or in aquatic environments in general.

Several recent studies have described local overgrazing of seagrass beds by sea turtles, as seagrass areas are diminishing, and turtle numbers have locally increased due to successful turtle conservation (Fourqurean and others 2010; Christianen and others 2014; Heithaus and others 2014). Overgrazing is defined here as changes in feeding behavior which can ultimately lead to ecosystem collapse. Overgrazing has caused local decline of seagrass meadows. A continued increase in turtle populations may thus compound existing threats to seagrass meadows caused by direct human-induced degradation of coastal environments (Lotze and others 2006; Waycott and others 2009). Moreover, whereas top-down control by predators may also ameliorate turtle grazing pressure (Heithaus and others 2014), protection mutualism may be more important than previously recognized.

In this study, we investigate whether a grazingprotection mutualism between seagrasses and unattached coralline algae can protect seagrass ecosystems from overgrazing by turtles. This type of coralline algae (belonging to the family Corallinaceae), seagrasses and turtles has strongly overlapping distribution ranging all over the tropical world (Figure 1), implying that the interactions among these species groups may have global significance. We first suspected such a mutualistic interaction, when we observed that a strong increase in unattached branched coralline algae in a tropical seagrass meadow was accompanied by changes in seagrass-specific composition and morphology typically associated with cessation of turtle grazing (Molina Hernández and van Tussenbroek 2014). Specifically, seagrass patches colonized by coralline algae shifted from dominance by a smaller fast-growing, grazing-resilient species (Halodule wrightii) to dominance of the larger, slow-growing climax species Thalassia testudinum that disappears when overgrazed (Figure 2). Therefore, we hypothesize that coralline algae facilitate seagrass by forming a dense layer of unpalatable hard structures that cover the nutrient-rich basal part of the seagrass shoots that turtles prefer to eat (Bjorndal 1980; Zieman and others 1984; Molina Hernández and van Tussenbroek 2014). We suggest that the seagrasses, in turn, facilitate the coralline algae by protecting them from being swept away by waves or currents, which allows the algae to thrive in areas with relatively high water movement (Steller and Foster 1995; Foster 2001).

To test our hypotheses, we carried out three complementary experiments. To test the first hypothesis that algae facilitate seagrass, we compared (1) grazing in ungrazed plots where we removed algae, and (2) in grazed plots where we placed algae. To test the second hypothesis that seagrass facilitates algae, we carried out a third experiment in which we placed algae in bare, grazed and ungrazed plots in a seagrass meadow, and measured displacement of the algae over time. 


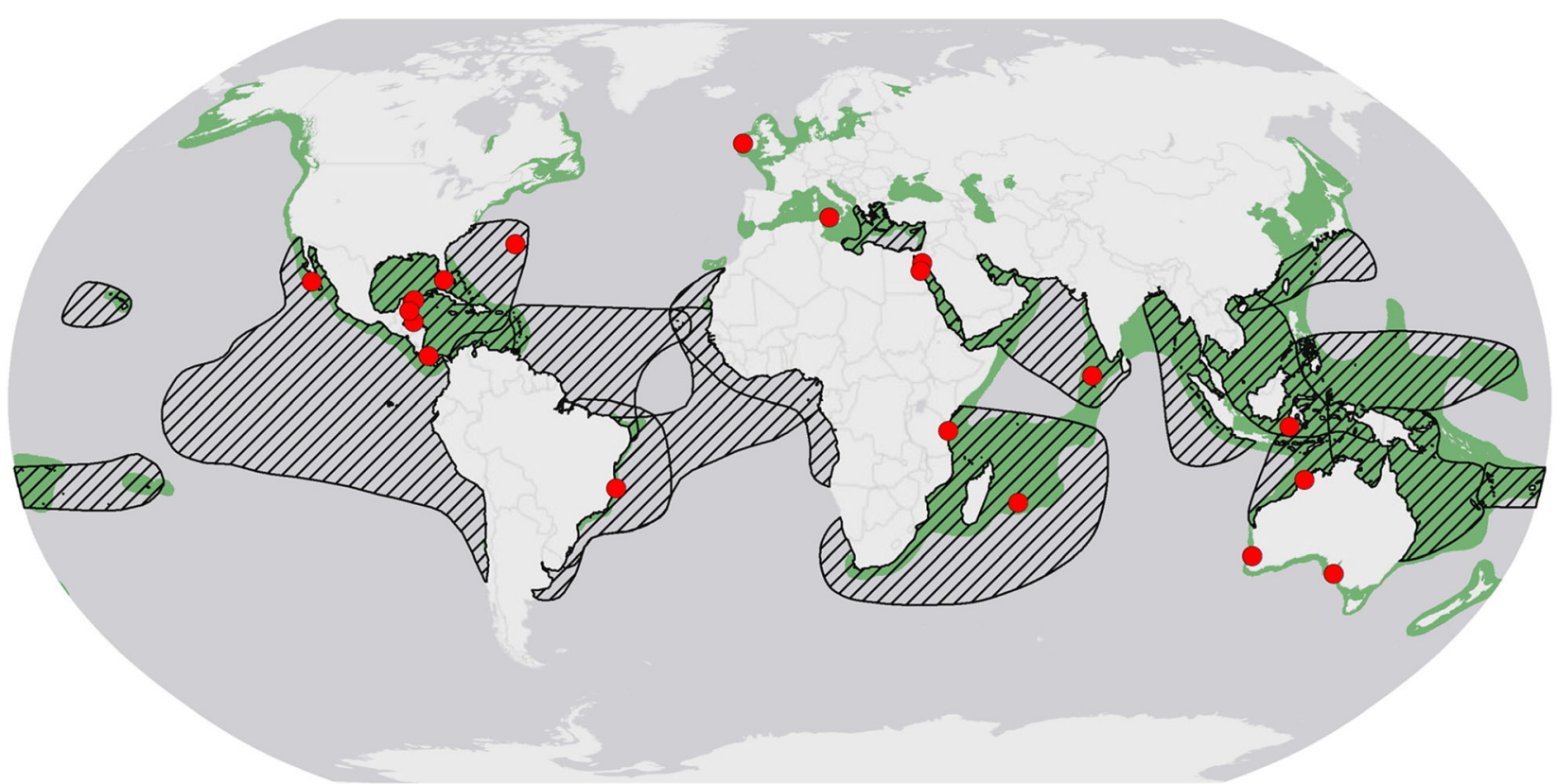

Figure 1. Distribution of seagrass beds (green), Chelonia mydas (striped) and literature accounts of unattached coralline algae associated with seagrass beds (red; Table S1). Seagrass data from Short (2017). C. mydas areas are regional management units, which encompass core habitats (Wallace and others 2010). Sources world map: Esri, DeLorme, HERE, MapmyIndia.

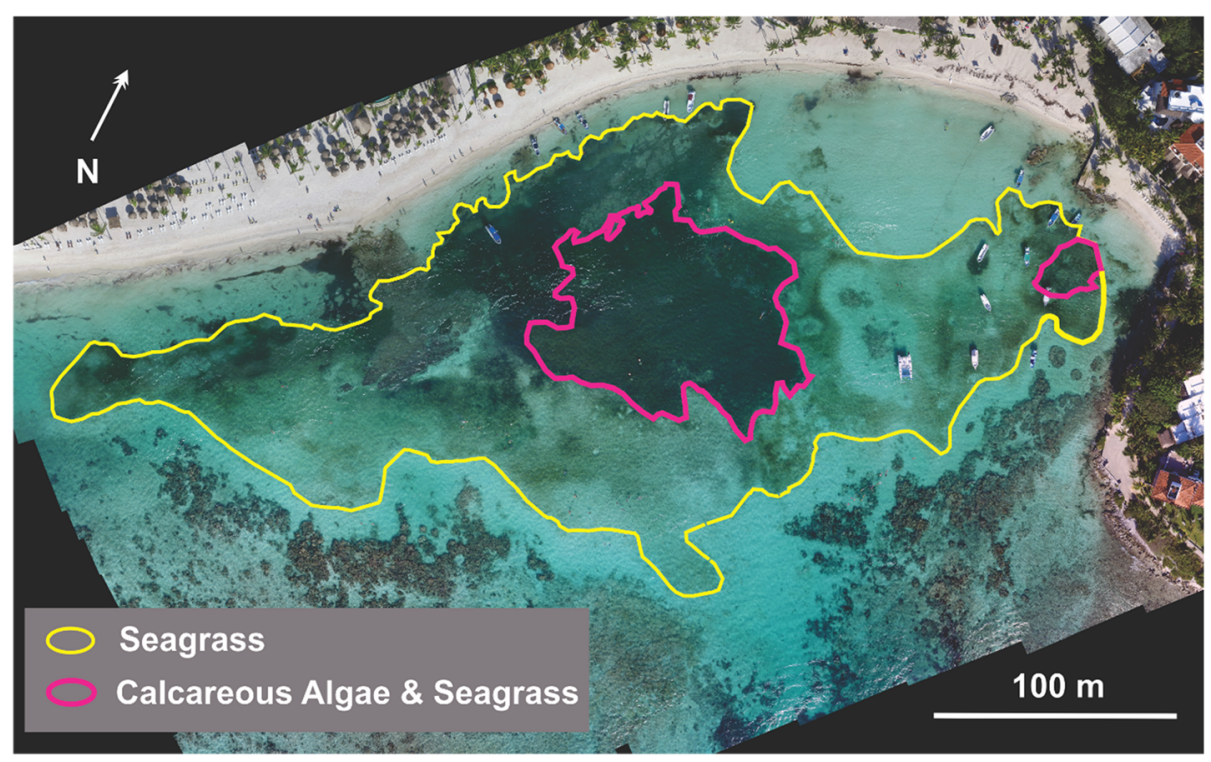

Figure 2. Contours of the seagrass bed in the northern section of Akumal Bay, and the sections of the bed with a thick layer of the coralline algae Neogoniolithon sp. and Amphiroa sp. The reefs are the stony formations fringing the seagrass bed at the seaward side (drone image from December 2016, verified with ground-truthing).

\section{Materials ANd Methods}

\section{Study Site}

We conducted our study in Akumal Bay (Mexican Caribbean, $20^{\circ} 23^{\prime} 44.9^{\prime \prime} \mathrm{N}, 87^{\circ} 18^{\prime} 47.9^{\prime \prime} \mathrm{W}$ ), a tropical bay protected by a fringing reef at about
100-300 m from the coast (Molina Hernández and van Tussenbroek 2014). Seagrass meadows in the lagoon cover about $\sim 4$ ha and experience high grazing pressure from a population of resident green turtles that has steadily increased over the last 2 decades (Maldonado Cuevas and others 
2006). Until 2008, the slow-growing climax seagrass species Thalassia testudinum was dominant at Akumal. By 2012, however, continuous excessive grazing pressure had caused this species to strongly decline and become replaced by the more grazingtolerant early seral species Halodule wrightii (Molina Hernández and van Tussenbroek 2014). There was serious concern that overgrazing was driving the seagrass ecosystem toward collapse (Molina Hernández and van Tussenbroek 2014). But such a collapse of the seagrass meadow has not occurred, while at the same time abundance of unattached red branched coralline algae (Neogoniolithon sp. and Amphiroa sp.) has increased greatly since 2012. Neogoniolithon sp. is a non-geniculate (not possessing non-calcified joints) alga, whereas Amphiroa sp. is geniculate (possesses uncalcified joints). These algae were very sparse in 2008 ( $<1 \%$ cover); they increased to about 3\% cover by 2012 with dense patches in some heavily grazed sections of the seagrass meadow and covered $\sim 20 \%$ of the bay in 2016 (B. I. van Tussenbroek, unpubl. data, Figure 2).

At the time of this study (Sep.-Nov. 2015), the algal aggregations formed a 3-6.8-cm-thick layer. Mean calcified weight was 5581 dry $\mathrm{g} \mathrm{m}^{-2}$, -with Neogoniolithon sp. accounting for approximately 90$95 \%$ of coralline algae biomass (Tables S2 and S3 for characterization of the coralline algae in the bay). The algae-covered section of the bay was colonized by $T$. testudinum, forming a dense and high canopy with a high above-and belowground biomass (Table S4), whereas Syringodium filiforme and $H$. wrightii had low biomass in this area. The coralline algae-free section of the bay was dominated by $H$. wrightii, and T. testudinum and S. filiforme had low biomass.

\section{Experiment 1-Do Algae Facilitate Seagrass?}

Experiment 1.1-Removal of Coralline Algae from Ungrazed Area

As a first step in testing the hypothesis that unattached branched coralline algae discourage turtles from grazing on seagrasses, we removed algae from the recovered seagrass meadow that was dominated by coralline algae. To this end, we haphazardly established $101 \times 1-\mathrm{m}$ plots from which we removed all coralline algae and 10 procedural control plots from which no algae were removed. To attract turtles to our experimental area, we mimicked turtle grazing in 20 -cm-wide strips around experimental and control plots by clipping seagrass to about $3 \mathrm{~cm}$ height [per (Molina Hernández and van Tussenbroek 2014)] and removing algae. Maintenance of the plots consisted of keeping the removal plots free of coralline algae and continued clipping of seagrass shoots in the 20$\mathrm{cm}$ 'turtle attraction strips' to about $3 \mathrm{~cm}$ height, when necessary.

Prior to the start of the experiment (14-9-2015), we measured general seagrass characteristics in the area. We determined leaf length and sheath length for all seagrass species at 10 haphazardly chosen locations (aprox. $2 \times 2 \mathrm{~m}$ in size) in the experimental area. For T. testudinum we also measured leaf width as an additional indicator. After 43 days, we terminated the experiment and re-measured all above-mentioned variables per plot.

Specifically, we collected 20 shoots of each seagrass species present per location (in the beginning) or plot (at termination of the experiment) by cutting their vertical rhizome below the sediment with a knife. In the laboratory, the lengths of the sheaths and green sections of all the leaves of the collected shoots were measured with a ruler, and leaf widths were measured with a dial caliper $(0.02-\mathrm{mm}$ precision). The blades were cleaned of epiphytes by scraping with a razor blade and placed in a drying oven at $60^{\circ} \mathrm{C}$ for at least $24 \mathrm{~h}$ until dry. The basal $3 \mathrm{~cm}$ of each leaf of $T$. testudinum was preserved for nutrient analysis following (Molina Hernández and van Tussenbroek 2014). Five times during the experiment, we visually estimated what percentage of the surface of the plots was newly grazed by turtles, which is clearly visible by the neatly cutoff leaves.

As a procedural control, we tested whether the turtle attraction strips caused an overestimation of grazing pressure within the plots. We compared shoots collected from the experimental site prior to the start of the experiment, with shoots collected from the procedural control plots at the end of the experiment. Next, we compared seagrass meadow characteristics in the removal versus procedural control plots to determine the effect of algae on grazing.

\section{Experiment 1.2-Addition of Coralline Algae to Grazed Area}

As a second test of the hypothesis that coralline algae deter turtles, we placed an approximately 5$\mathrm{cm}$-thick layer of algae, originating from the ungrazed seagrass meadow, on the grazed meadow in 10 haphazardly chosen $1 \times 1 \mathrm{~m}$ plots. The same measurements were taken as in experiment 1.1, both at the start and at the end of the experiment. 
Maintenance of the plots consisted of maintaining the algae layer by topping up coralline algae in the plots when algae were displaced by water movement, tourists or animals, or when they were covered with sand by mantis shrimp. The experiment was initiated on 9-9-2015 and lasted for 48 days. The turtles continued to graze the areas around the plots during the experiment. We analyzed our treatment effect by comparing seagrass meadow characteristics before and after the addition treatment.

\section{Experiment 2-Do Seagrasses Facilitate Algae?}

To determine the effect of seagrass vegetation on establishment of unattached coralline algae, we placed thalli of Neogoniolithon sp. in ungrazed, turtle-grazed and bare sand patches in a seagrass meadow at Puerto Morelos $\left(20^{\circ} 50^{\prime} 27.2^{\prime \prime} \mathrm{N}, 86^{\circ}\right.$ $\left.52^{\prime} 26.1^{\prime \prime} \mathrm{W}\right)$. Locations were undisturbed by tourists. We established 3 replicate patches per treatment, and in each patch $20 \mathrm{~g}$ (wet weight) of algae was placed in a $10 \times 10 \mathrm{~cm}$ quadrat. The quadrat was removed, and small sticks were left to indicate the exact position. One week later, the $10 \times 10 \mathrm{~cm}$ quadrat was placed back at the exact same location, with an $80 \times 80 \mathrm{~cm}$ quadrat around it. The algae in both quadrats were collected separately, transported to the laboratory and weighed, to determine whether they persisted at the same location $(10 * 10 \mathrm{~cm}$ quadrat) or in the general area $(80 * 80 \mathrm{~cm}$ quadrat). After 7 days the algae were collected, as we already saw considerable removal already occurring in the plots.

\section{Statistics}

Data were analyzed with R (v. 3.4.1, R Development Core Team 2017). Unless stated otherwise, mean \pm standard deviation is used to show the variability of parameters in this study. When $N$ is given for nested data it refers to the number of subjects, not to the total number of measurements $(n)$. When SD is given for nested data, it is of subject means. To compare groups with nested and random factors, a generalized linear mixed model (hereafter GLMM) was used, followed up by a Tukey's post hoc test when there were more than two groups. For comparisons between groups without nested and random factors, a Welch twosample $t$ test was used when there were two groups, and a one-way ANOVA when there were more than two groups. Count data were subjected to square root transformation before analysis.
Other data were modeled untransformed, square root transformed and log transformed, after which a Shapiro-Wilk test of normality was performed on model residuals and the model with the most normally distributed residuals was chosen. To calculate denominator degrees of freedom $\left(\mathrm{d} f^{2}\right)$ in GLMM, Satterthwaite approximation was used.

\section{Results}

\section{Experiment 1-Do Algae Facilitate Seagrass?}

\section{Experiment 1.1-Removal of Coralline Algae from Un- grazed Area}

Nine days after the start of the experiment, 7 algae removal plots already had more than $50 \%$ of their seagrass shoots grazed by turtles. (Turtle grazing is identified by distinct bite marks and pattern.) By the end of the experiment after 43 days, this had increased to 10 plots with greater than $95 \%$ of all seagrass shoots being grazed (Figure 3). In contrast, only about $50 \%$ of the seagrass shoots in control plots were grazed at the end of the experiment (comparing control with removal: $p=0.006$,

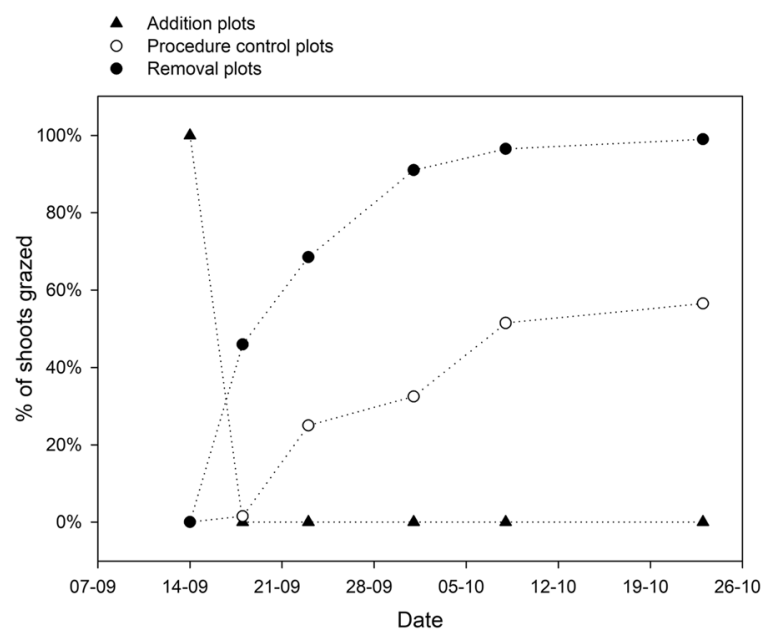

Figure 3. Visual estimation of \% of plot surface recently grazed by turtles. Coralline algae were removed from the recovering part of the meadow, where also a procedural control was installed (turtle attraction but no algae removal, part of experiment 1.1), and added in a grazed area (experiment 1.2). Turtle herbivory was indicated by typical bite marks on shortened seagrass leaves. Experiments were initiated on 14-09; grazing was estimated 5 times during the experiment. Values are mean values $(n=10$ for both treatments). In general, seagrasses in removal plots were grazed to $\sim 3 \mathrm{~cm}$ above the sediment, while seagrasses in control plots, if grazed, were almost always only grazed to several $\mathrm{cm}$ above the coralline algae layer. 
Welch $t$ test). Note that this was significantly higher than the initial proportion of grazed shoots $(p=0.001$, Welch $t$ test), illustrating the $20-\mathrm{cm}$ wide clipped strips around the control and treatment plots functioned to attract turtles to the site as intended. For photographs of the experiment see Figure 4.

Apart from clear differences in the proportion of grazed leaves, leaf morphology also differed between treatments. In the removal plots, green leaf and sheath lengths of T. testudinum, S. filiforme and sheath length of $H$. wrightii were significantly shorter than in control plots (Figure 5, plots as random factor in GLMM) and had similar dimensions as plants in algae-free grazed areas in other parts of the meadow (Table S5). Leaf width of $T$. testudinum was reduced from $9.7 \pm 1.2$ to $7.5 \pm 0.8 \mathrm{~mm}$ in removal plots, whereas in control plots it was $9.3 \pm 0.7$. Note that, similar to the proportion of grazed shoots, the dimensions of the

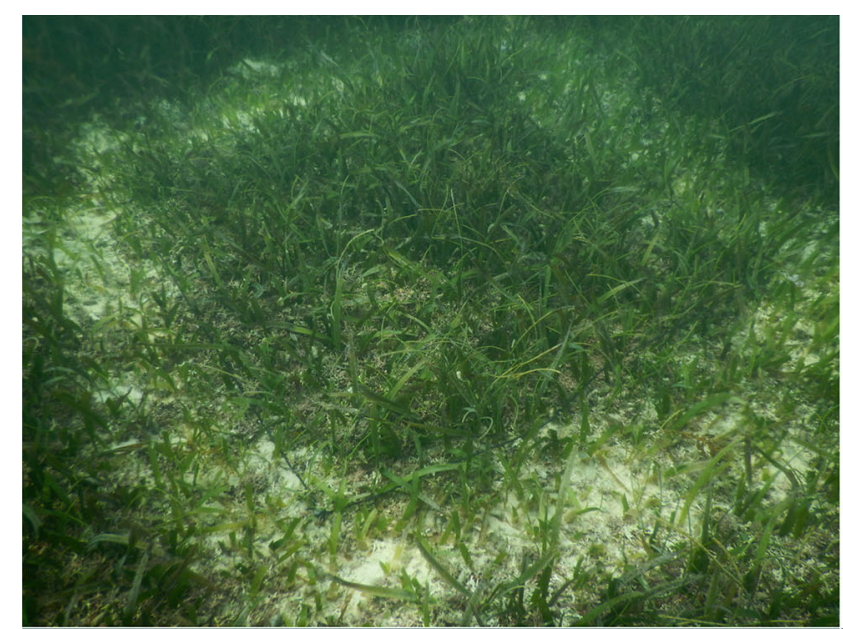

plants illustrate that the attraction strips functioned well; all seagrass parameters were significantly reduced in control plots in the course of the experiment (Table 1).

Elemental analysis of the basal $3 \mathrm{~cm}$ of $T$. testudinum leaves showed significantly higher concentrations of nitrogen (2.87 vs. 2.36 mass\%; Welch $t$ test, $p=0.0016$ ), phosphorus (46.8 vs. $39.8 \mu \mathrm{mol} / \mathrm{g} ; p=0.012)$, iron ( $1.37 \mathrm{vs} .1 .08 \mu \mathrm{mol} /$ g; $p=0.032)$ and other elements in removal plots compared to control plots (see Table S6 for complete results of elemental analysis).

\section{Experiment 1.2-Addition of Coralline Algae to Grazed Area}

The turtles fully ceased grazing the plots following the addition of coralline algae to the grazed seagrass plots, as we did not record any cut leaves in the plots over the course of the experiment (Figure 3, plots as random factor in GLMM). Moreover, the
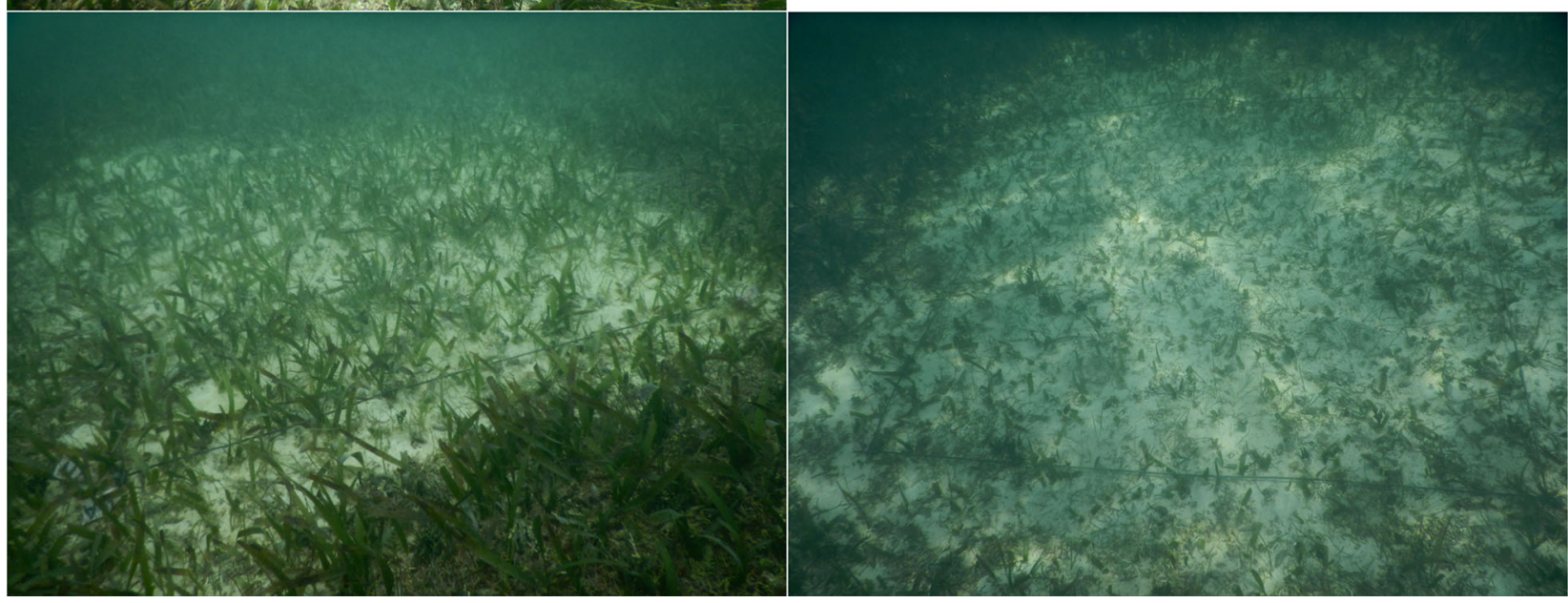

Figure 4. Control plot with coralline algae; note that a $20-\mathrm{cm}$ turtle attraction strip was created around the plot by removing the algae and clipping the seagrass (top), algae removal treatment plot at start of the experiment (bottom left) and same plot 5 days later, after turtles visited (bottom right). 

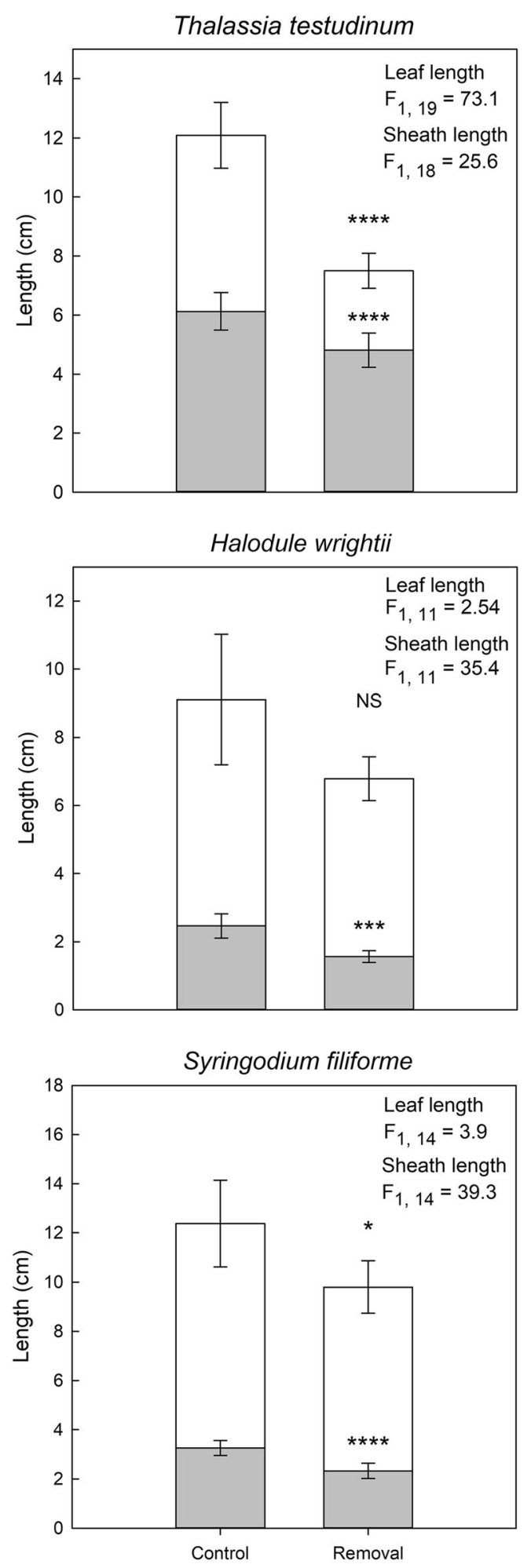

Figure 5. Mean length $( \pm \mathrm{SD})$ of green leaf sections (white) and sheaths (gray) of seagrass shoots in algae removal plots compared with control plots (experiment 1.1) for all 3 seagrass species. GLMM performed. Asterisks indicate significance level of the difference between treatments $(*<0.05, * *<0.01, * * *<0.001$, $* * * *<0.0001$, NS not significant). addition of algae led to significantly increased leaf and sheath length of all three seagrass species at the end of the experiment after 48 days (Figures 6, 7). Thalassia testudinum leaf width did not change.

\section{Experiment 2-Do Seagrasses Facilitate Algae?}

Seagrass vegetation had a significant effect on retention of Neogoniolithon sp. in the $10 \times 10 \mathrm{~cm}$ quadrats where we originally added the algae (GLMM: $F_{2,6}=11.0, P=0.01$, replicate quadrats as random factor), and in the surrounding $80 \times 80$ $\mathrm{cm}$ quadrats to which the algae dispersed $\left(F_{2,6}=17.6, P=0.003\right)$. One week after placing about $20 \mathrm{~g}$ of Neogoniolithon $\mathrm{sp}$. in $10 \times 10 \mathrm{~cm}$ quadrats in different locations, none were still in place in the bare areas, while $27.6 \% \pm 12.8$ and $67.3 \% \pm 5.3 \%$ were still present at the grazed and ungrazed sites, respectively (Figure 8). Post hoc comparisons revealed that the difference between ungrazed and grazed sites was significant, as was the difference between ungrazed and bare sites. When the search was extended to an $80 \times 80 \mathrm{~cm}$ quadrat around the initial $10 \times 10$ plots, we still did not retrieve any algae from the bare areas, while $55.2 \% \pm 8.81$ and $72.1 \% \pm 3.94$ were retrieved from the grazed and ungrazed sites, respectively. Here, post hoc comparisons showed that the difference between bare and grazed sites was significant, as was the difference between bare and ungrazed sites (Figure 8).

\section{DisCUSSION}

Recent studies suggest that an intact trophic network is often vital for the conservation of seagrass ecosystems and the recovery of degraded meadows (Lotze and others 2006; Waycott and others 2009; Ferretti and others 2010; Fourqurean and others 2010; Hughes and others 2013). Although topdown control of grazers by their predators is a wellknown mechanism controlling grazing pressure in coastal ecosystems such as salt marshes and seagrass meadows (Silliman and Bertness 2002; Hughes and others 2013), studies from terrestrial systems demonstrate that protection mutualisms can also reduce grazing pressure (Janzen 1969; Schupp 1986). Here, we experimentally demonstrate that unattached coralline algae mediate the recovery of overgrazed seagrass meadows by deterring grazing green turtles, while seagrasses facilitate the algae by stabilizing the unattached coralline algae on the soft-sediment seabed. There are very few examples of plant-plant mutualistic 
Table 1. Comparison of Seagrass Characteristics in the Algae-Covered Section of the Bay Prior to the Experiment $(t=0)$ and in Procedure Control Plots $(t=1)$

\begin{tabular}{|c|c|c|c|c|c|}
\hline & Ungrazed area $(t=0)$ & Control plots $(t=1)$ & $p$ & $\mathrm{~d} f$ & $t$ \\
\hline \multicolumn{6}{|l|}{ Thalassia testudinum } \\
\hline Leaf length $(\mathrm{cm})$ & $11.0 \pm 2.4$ & $6.0 \pm 1.1$ & $2.20 \mathrm{E}-16$ & 816.5 & 15.7 \\
\hline Sheath length $(\mathrm{cm})$ & $7.4 \pm 1.4$ & $6.1 \pm 0.6$ & $2.20 \mathrm{E}-16$ & 881.7 & 11.6 \\
\hline Leaf width (mm) & $9.7 \pm 1.2$ & $9.3 \pm 0.7$ & $6.75 \mathrm{E}-06$ & 901.5 & 4.53 \\
\hline \multicolumn{6}{|l|}{ Halodule wrightii } \\
\hline Leaf length $(\mathrm{cm})$ & $8.2 \pm 1.2$ & $6.6 \pm 1.9$ & 0.000347 & 556.3 & 3.60 \\
\hline Sheath length $(\mathrm{cm})$ & $3.6 \pm 0.4$ & $2.5 \pm 0.4$ & $2.20 \mathrm{E}-16$ & 557.1 & 16.9 \\
\hline \multicolumn{6}{|l|}{ Syringodium filiforme } \\
\hline Leaf length $(\mathrm{cm})$ & $13.3 \pm 3.1$ & $9.1 \pm 1.8$ & $3.12 \mathrm{E}-11$ & 401.6 & 6.83 \\
\hline Sheath length $(\mathrm{cm})$ & $3.5 \pm 0.5$ & $3.3 \pm 0.3$ & 0.000309 & 361.3 & 3.64 \\
\hline
\end{tabular}

interactions (Tirado and others 2015), and plantplant mutualisms involving grazing protection have only been reported from terrestrial systems (Tirado and others 2015; Queijeiro-Bolaños and others 2017). Our study shows that aquatic plantplant grazing-protection mutualisms exist and in fact can be vital for the maintenance and recovery of ecosystems shaped by habitat-structuring foundation species.

\section{How Algae Facilitate Seagrass}

High numbers of turtle bite marks combined with changes in seagrass shoot morphology, clearly show that removal of unattached coralline algae from an ungrazed seagrass meadow caused turtles to resume grazing, whereas addition of algae to a grazed meadow dramatically reduced turtle grazing. These results support our hypothesis that recovery of the seagrass meadow at Akumal is at least in part due to protection offered by the algae. The most likely mechanism underlying the repelling effect of coralline algae on turtles is that the spikey 3D structure of the algae may directly hamper grazing by turtles. The algae obstruct the turtles and in addition may physically harm the eyes of the turtles as they try to reach the preferred lower basal parts $(\sim 3 \mathrm{~cm})$ of the shoots (Zieman and others 1984; Molina Hernández and van Tussenbroek 2014).

The effects of changed grazing pressure from turtles as a result of the treatments differed per seagrass species. We found that while leaves of $T$. testudinum were intensively grazed upon when we removed the coralline algae, as evidenced from the $55 \%$ reduction in leaf average length, leaf length reductions of $S$. filiforme were smaller and nonsignificant for $H$. wrightii. This implies that, in accordance with earlier findings, $T$. testudinum was preferentially grazed by the turtles (Molina Hernández and van Tussenbroek 2014). The addition of coralline algae to the grazed seagrass meadow caused a $78 \%$ increase in the average leaf length of T. testudinum within 45 days (Figure 6, Table S5), suggesting that the turtles completely ceased grazing. This is in accordance with the personal observation that leaves likely formed during the experimental period (based on their length) did not have turtle grazing scars. In a turtle exclosure experiment in Bermuda, Fourqurean and others (2010) saw an increase in T. testudinum leaf length from 40 to $66 \mathrm{~mm}$ after 1 year of excluding turtles. The fact that we saw such a rapid increase after cessation of grazing, from 32 to $57 \mathrm{~mm}$ in just 45 days, may be attributed to faster growth due to higher nutrient levels at our study site, indicated by much lower C:N ratios (14.1 and 15.7 for grazed and ungrazed areas at our study site, compared to 16.1 and 26.1 at Bermuda) and C:P ratios (208 and 328 for grazed and ungrazed areas at our study site, compared to 852 and 622 at Bermuda) of T. testudinum leaf tissue.

Seagrass leaf tissue (fresh growth, the lower basal parts) in removal plots had higher nutrient content than in control plots, which happens when seagrass is grazed and is one of the reasons that sea turtles return to the same grazed patches of seagrass (Thayer and others 1984; Martínez-López and others 2019).

\section{How Seagrasses Facilitate Algae}

Our third experiment demonstrates that unattached coralline algae can only thrive within the seagrass meadows in our study area. In fact, the algae disappeared from bare areas within 7 days, 

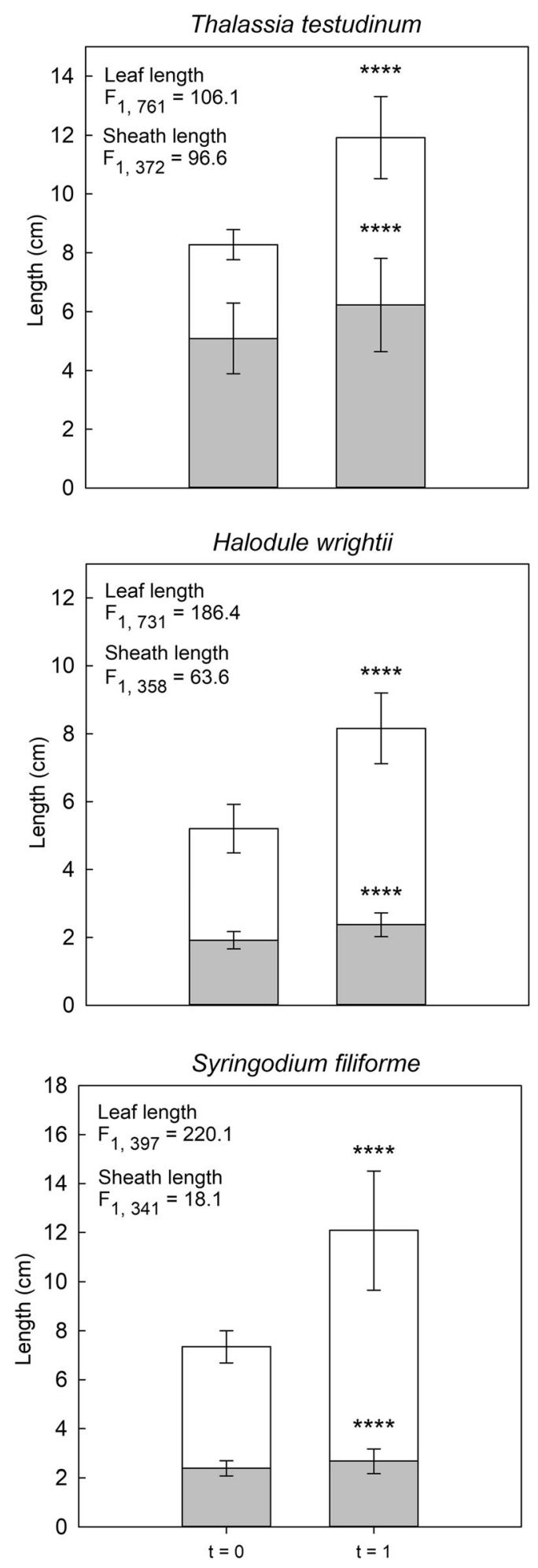

Figure 6. Mean length $( \pm \mathrm{SD})$ of green leaf sections (white) and sheaths (gray) of seagrass shoots in algae addition experiment (experiment 1.2) at $t=0$ and 48 days after addition of algae. GLMM performed. Asterisks indicate significance level of the difference $\left(*<0.05,{ }^{* *}<0.01,{ }^{* * *}<0.001, * * * *<0.0001\right.$, NS not significant).

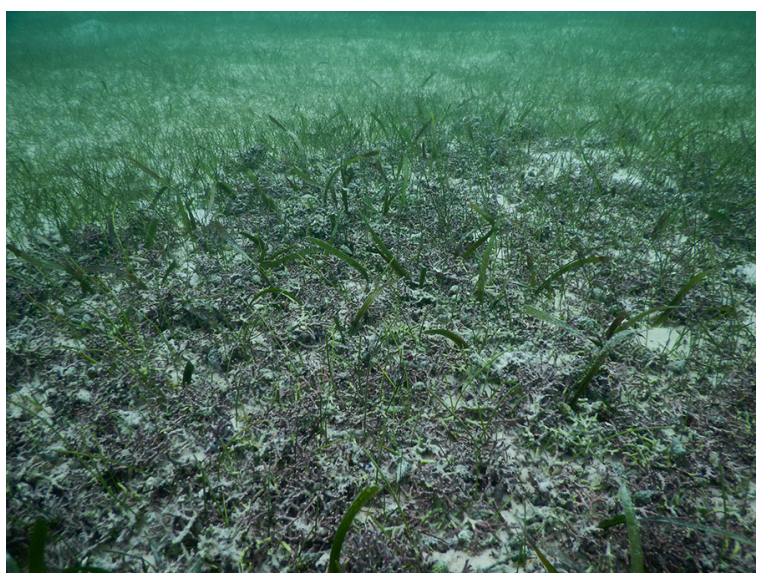

Figure 7. Algae addition plot (the purple-greyish area) at the end of the experiment showing the recovery of Thalassia testudinum. Outside the plot, only Halodule wrightii is visible.

suggesting that currents and waves, possibly in interaction with unstable sediments, caused the algae to wash away. In contrast, algae remained rather stable in sparse, formerly grazed seagrass patches and even more so in dense, ungrazed parts of the meadow. This can be explained by the capacity of seagrasses to attenuate currents and waves, and stabilize sediments (van der Heide and others 2007; Christianen and others 2013; Maxwell and others 2017). High densities of unattached coralline algae typically occur in areas with sufficient light for growth and moderate water movement that prevents burial by sediment while remaining low enough to prevent the algae from being flushed away or destroyed (Foster 2001). Our study provides experimental evidence that, by reducing physical stress, seagrasses allow unattached coralline algae to thrive in environments that would otherwise not be suitable.

Our findings raise the question why unattached coralline algae are not more abundant in seagrass meadows. While there are reports of coralline algae in seagrass meadows (Figure 1), most observations suggest that they tend to occur around the edges of the meadow or in depressions, and individuals inside the meadow are often scarce and scattered (Bosellini and Ginsburg 1971; Bosence 1985; Piller and Rasser 1996; Basso and others 2008; Freile and Devore 2016). In our study system, the algae were previously found in $T$. testudinum meadows, but only between sparse vegetation (Vásquez-Elizondo and Enríquez 2016) and growing in small patches in denser meadows (Ruiz-Zárate and others 2000). The formation of a dense mat of unattached coralline algae in Akumal only started after turtles 

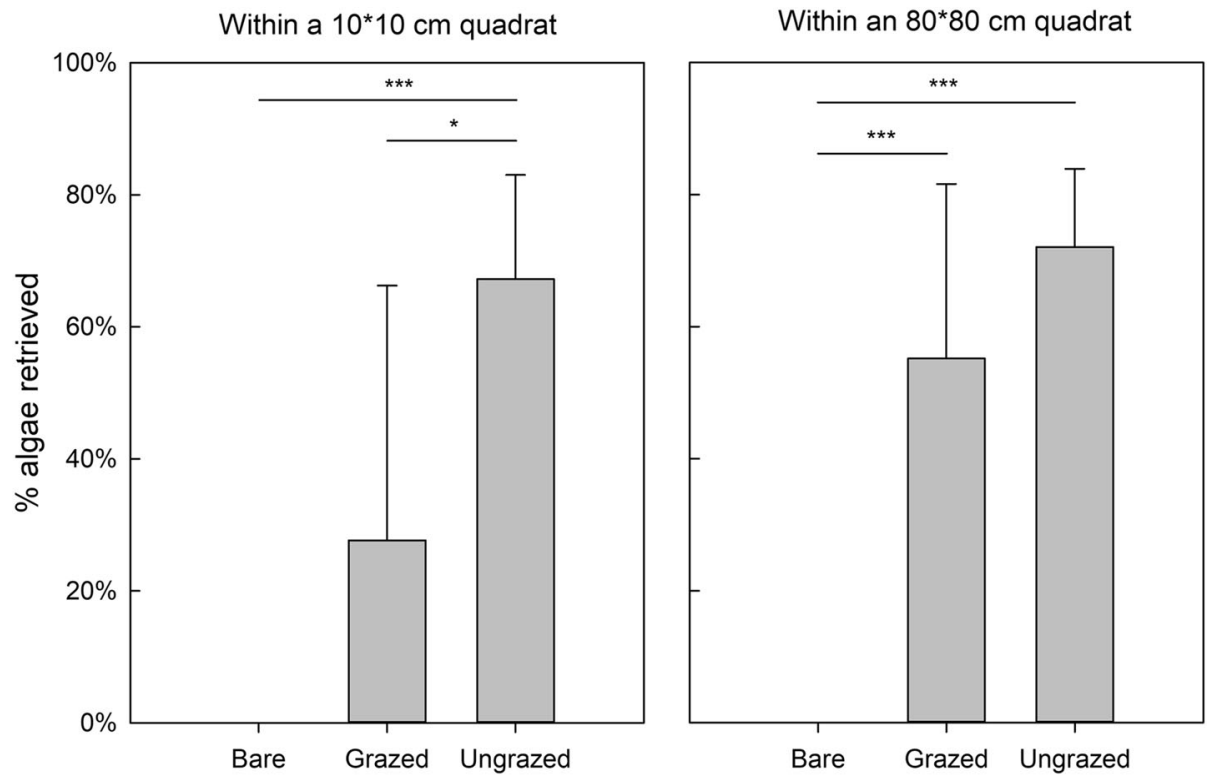

Figure 8. Mean retrieval \% $( \pm \mathrm{SD})$ of Neogoniolithon sp. after one week in the near vicinity $($ within $10 \times 10 \mathrm{~cm}$, left $)$ or wider vicinity (within $80 \times 80 \mathrm{~cm}$, right), in three vegetation types after 1 week. Lines over bars indicate which groups significantly differ (GLMM, Tukey's HSD test). Asterisks indicate significance level of the difference between treatments $(*<0.05, * *<0.01, * * *<0.001)$.

grazed the entire seagrass meadow in the bay instead of just patches (Molina Hernández and van Tussenbroek 2014). The grazing may have facilitated algae growth due to increased light availability, while the meadow still provided ample protection from hydrodynamics. As the rapid colonization by the algae in turn facilitated seagrass growth, it is possible that the seagrass-algae interaction may over time gradually shift from mutualism to competition as the growing seagrass canopy will inevitably increase shading of the algae. The mutualism then only exists in the intermediate grazing range, which would explain the absence of large algae densities in dense seagrass meadows. Such shifts in the nature of species interactions have been commonly reported from other systems (Bronstein 1994)—facilitation can shift to antagonism or vice versa when environmental conditions change.

\section{Implications}

Although the mutualistic seagrass-algae interaction allows for rapid recovery of the overgrazed seagrass meadows in Akumal, an important potential downside may be that a continued expansion of the coralline algae may eventually exclude turtles in large parts of the bay. If this would indeed happen, the remaining seagrass area may become too small to sustain the turtle population as it is currently estimated to be at or near carrying capacity (Molina
Hernández and van Tussenbroek 2014). Turtles may shift diet from seagrass to filamentous algae, if available (Bjorndal 1980; Santos and others 2015), or have to move to another area. If turtles do not or cannot change diet or relocate their feeding grounds, they may be forced to start grazing the coralline algae-covered parts of the meadow. If they do so in the same manner as we observed in the procedural control plots of the removal experiment, that is, grazing while leaving the lower $3 \mathrm{~cm}$ of the leaves intact, algae may still prevent or slow down overgrazing. The photosynthetic tissue preserved by this less intensive form of grazing may reduce or even prevent depletion of belowground carbohydrate reserves. However, another scenario could be that under continued high grazing pressure the mutualism breaks down, depending on whether the turtles prefer to relocate or, possibly by necessity, choose to deal with the nuisance of the algae.

Ecosystem-based conservation and restoration approaches in coastal ecosystems are increasingly advocated, as many studies from coral reefs, salt marshes and seagrasses emphasize the importance of ecological interaction networks for ecosystem functioning (Angelini and others 2015; van der Zee and others 2016; Derksen-Hooijberg and others 2018). Our current work highlights that recovery of mutualistic interactions can help preserve and recover tropical seagrass meadows. Although 
promising, we emphasize that introducing species as a biological control measure must always be done with great caution and after careful risk assessment (Howarth 2000). However, unattached coralline algae have a global distribution with much overlap with that of seagrasses and turtles. In fact, Figure 1 is in that sense by no means an exhaustive account, as these algae are widespread and new growth sites continue to be discovered (Riosmena-Rodríguez and others 2016). This implies that algae can probably be locally sourced in many areas and used with little risk of introducing exotic species. We therefore conclude that seeding coralline algae with the aim of protecting or recovering threatened seagrass meadows deserves further attention, as it has potential to be a cheap and effective protection measure in tropical seagrass meadows around the world.

\section{ACKNOWLEDGEMENTS}

We thank Maria Guadelupe Barba Santos, Nancy Estefany Burgos Veneroso and Veronica Monroy Velázquez for supporting this study in the field or laboratory, Rens Cronau and Ward Kleuskens for performing Experiment 2, the Cooperativa Piratas de Akumal S.C. de R.L. for their logistic support in Akumal, Edgar Escalante-Mancera \& Miguel-Angel Gómez from Servicio Académico de Monitoreo Meteorológico y Oceanográfico (ICML Puerto Morelos) for providing the drone image from Figure 2 and Sebastian Krosse and Paul Van Der Ven of General Instrumentation of the Radboud University for conducting the chemical analyses. This study is part of Isis G. Martínez PhD project at the postgraduate program Posgrado en Ciencias del Mar y Limnología (PCMyL) of the Universidad Nacional Autónoma de México (UNAM) with a CONACYT (Consejo Nacional de Ciencia y Tecnologia) fellowship.

\section{OPEN ACCESS}

This article is licensed under a Creative Commons Attribution 4.0 International License, which permits use, sharing, adaptation, distribution and reproduction in any medium or format, as long as you give appropriate credit to the original author(s) and the source, provide a link to the Creative Commons licence, and indicate if changes were made. The images or other third party material in this article are included in the article's Creative Commons licence, unless indicated otherwise in a credit line to the material. If material is not included in the article's Creative Commons licence and your intended use is not permitted by statutory regulation or exceeds the permitted use, you will need to obtain permission directly from the copyright holder. To view a copy of this licence, visit $h$ ttps://creativecommons.org/licenses/by/4.0/

\section{DATA ACCESSIBILITY}

Data is archived through the Data Archiving and Networked Services (DANS), of the Koninklijke Nederlandse Academy van Wetenschappen (KNAW, Royal Dutch Academy of Sciences). http s://doi.org/10.17026/dans-25p-82rx.

\section{REFERENCES}

Angelini C, van der Heide T, Griffin JN, Morton JP, DerksenHooijberg M, Lamers LPM, Smolders AJP, Silliman BR. 2015. Foundation species' overlap enhances biodiversity and multifunctionality from the patch to landscape scale in southeastern United States salt marshes. Proc R Soc B Biol Sci 282:20150421.

Basso D, Bernasconi MP, Robba E, Marozzo S. 2008. Environmental evolution of the marsala sound, sicily, during the last 6000 years. J Coast Res 241:177-97.

Bjorndal KA. 1980. Nutrition and grazing behavior of the green turtle Chelonia mydas. Mar Biol 56:147-54.

Bosellini A, Ginsburg RN. 1971. Form and internal structure of recent algal nodules (Rhodolites) from Bermuda. J Geol 79:669-82.

Bosence DWJ. 1985. The morphology and ecology of a moundbuilding coralline alga (Neogoniolithon strictum) from the Florida keys. Palaeontology 28:189-206.

Bronstein JL. 1994. Conditional outcomes in mutualistic interactions. Trends Ecol Evol 9:214-17.

Bruno JF, Stachowicz JJ, Bertness MD. 2003. Inclusion of facilitation into ecological theory. Trends Ecol Evol 18:119-25.

Christianen MJ, Herman PM, Bouma TJ, Lamers LP, van Katwijk MM, van der Heide T, Mumby PJ, Silliman BR, Engelhard SL, van de Kerk M, Kiswara W, van de Koppel J. 2014. Habitat collapse due to overgrazing threatens turtle conservation in marine protected areas. Proc R Soc B Biol Sci 281:20132890.

Christianen MJ, van Belzen J, Herman PM, van Katwijk MM, Lamers LP, van Leent PJ, Bouma TJ. 2013. Low-canopy seagrass beds still provide important coastal protection services. PLOS ONE 8:e62413.

de Fouw J, Govers LL, van de Koppel J, van Belzen J, Dorigo W, Sidi Cheikh MA, Christianen MJ, van der Reijden KJ, van der Geest M, Piersma T, Smolders AJ, Olff H, Lamers LP, van Gils JA, van der Heide T. 2016. Drought, mutualism breakdown, and landscape-scale degradation of seagrass beds. Curr Biol 26:1051-6.

Derksen-Hooijberg M, Angelini C, Lamers LPM, Borst A, Smolders A, Hoogveld JRH, de Paoli H, van de Koppel J, Silliman BR, van der Heide T. 2018. Mutualistic interactions amplify saltmarsh restoration success. J Appl Ecol 55:405-14.

Ferretti F, Worm B, Britten GL, Heithaus MR, Lotze HK. 2010. Patterns and ecosystem consequences of shark declines in the ocean. Ecol Lett 13:1055-71.

Foster MS. 2001. Rhodoliths: between rocks and soft places. J Phycol 37:659-67. 
Fourqurean JW, Manuel S, Coates KA, Kenworthy WJ, Smith SR. 2010. Effects of excluding sea turtle herbivores from a seagrass bed: overgrazing may have led to loss of seagrass meadows in Bermuda. Mar Ecol Progr Ser 419:223-32.

Freile D, Devore M. 2016. Mixed genera shallow water rhodoliths from Roatán, Honduras. In: Proceedings of the 16th Symposium on the Geology of the Bahamas and other Carbonate Regions. Gerace Research Centre, San Salvador, Bahamas, pp. 141-153.

Hay ME, Parker JD, Burkepile DE, Caudill CC, Wilson AE, Hallinan ZP, Chequer AD. 2004. Mutualisms and aquatic community structure: the enemy of my enemy is my friend. Ann Rev Ecol Evol Syst 35:175-97.

Heithaus MR, Alcoverro T, Arthur R, Burkholder DA, Coates KA, Christianen MJA, Kelkar N, Manuel SA, Wirsing AJ, Kenworthy WJ, Fourqurean JW. 2014. Seagrasses in the age of sea turtle conservation and shark overfishing. Front Mar Sci $1: 28$.

Hemminga MA, Duarte CM. 2000. Seagrass ecology. Cambridge: Cambridge University Press.

Howarth FG. 2000. Non-target effects of biological control agents. In: Gurr G, Wratten S, Eds. Biological control: measures of success. Netherlands: Springer. p 369-403.

Hughes BB, Eby R, Van Dyke E, Tinker MT, Marks CI, Johnson KS, Wasson K. 2013. Recovery of a top predator mediates negative eutrophic effects on seagrass. Proc Natl Acad Sci USA 110:15313-18.

Janzen DH. 1969. Allelopathy by myrmecophytes: the ant azteca as an allelopathic agent of cecropia. Ecology 50:147-53.

Lotze H, Lenihan H, Bourque B, Bradbury R, Cooke R, Kay M, Kidwell S, Kirby M, Peterson C, Jackson J. 2006. Depletion, degradation, and recovery potential of estuaries and coastal seas. Science 312:1806-9.

Maldonado Cuevas M, Lorences-Camargo A, Sánchez-Navarro P. 2006. Estudio técnico justificativo para el establecimiento del área de refugio para la protección de tortugas marinas de la bahías de Akumal., Akumal, Mexico.

Martínez-López I, Akker M, Walk L, Katwijk M, Heide T, Tussenbroek B. 2019. Nutrient availability induces community shifts in seagrass meadows grazed by turtles. PeerJ 7:e7570.

Maxwell PS, Eklf JS, van Katwijk MM, O'Brien KR, de la TorreCastro M, Bostrm C, Bouma TJ, Krause-Jensen D, Unsworth RK, van Tussenbroek BI. 2017. The fundamental role of ecological feedback mechanisms for the adaptive management of seagrass ecosystems-a review. Biol Rev 92:1521-38.

Molina Hernández AL, van Tussenbroek BI. 2014. Patch dynamics and species shifts in seagrass communities under moderate and high grazing pressure by green sea turtles. Mar Ecol Progr Ser 517:143-57.

Piller WE, Rasser M. 1996. Rhodolith formation induced by reef erosion in the Red Sea, Egypt. Coral Reefs 15:191-8.

Queijeiro-Bolaños ME, González EJ, Martorell C, Cano-Santana Z. 2017. Competition and facilitation determine dwarf mistletoe infection dynamics. J Ecol 105:775-85.

Riosmena-Rodríguez R, Nelson W, Aguirre J. 2016. Rhodolith/ Maërl Beds: a global perspective. Switzerland: Springer.

Ruiz-Zárate MA, Espinoza-Avalos J, Carricart-Ganivet JP, Fragoso D. 2000. Relationships between Manicina areolata (Cnidaria: Scleractinia), Thalassia testudinum (Anthophyta) and Neogoniolithon sp. (Rhodophyta). Mar Ecol Progr Ser 206:13546.
Santos RG, Martins AS, Batista MB, Horta PA. 2015. Regional and local factors determining green turtle Chelonia mydas foraging relationships with the environment. Mar Ecol Progr Ser 529:265-77.

Schupp EW. 1986. Azteca protection of Cecropia: ant occupation benefits juvenile trees. Oecologia 70:379-85.

Short FT. 2017. Global distribution of seagrasses (version 5.0). Fourth update to the data layer used in Green and Short (2003). Cambridge: UN Environment World Conservation Monitoring Centre.

Silliman BR, Bertness MD. 2002. A trophic cascade regulates salt marsh primary production. Proc Natl Acad Sci 99:10500.

Stachowicz JJ. 2001. Mutualism, facilitation, and the structure of ecological communities. BioScience 51:235-46.

Steller DL, Foster MS. 1995. Environmental factors influencing distribution and morphology of rhodoliths in Bahía Concepción, B.C.S., México. J Exp Mar Biol Ecol 194:201-12.

Thayer G, Bjorndal K, Ogden J, Williams S, Zieman J. 1984. Role of larger herbivores in seagrass communities. Estuaries 7:35176.

Tirado R, Bråthen KA, Pugnaire FI. 2015. Mutual positive effects between shrubs in an arid ecosystem. Sci Rep 5:14710.

Toby Kiers E, Palmer TM, Ives AR, Bruno JF, Bronstein JL. 2010. Mutualisms in a changing world: an evolutionary perspective. Ecol Lett 13:1459-74.

van der Heide T, Govers LL, de Fouw J, Olff H, van der Geest $M$, van Katwijk MM, Piersma T, van de Koppel J, Silliman BR, Smolders AJ, van Gils JA. 2012. A three-stage symbiosis forms the foundation of seagrass ecosystems. Science 336:1432-4.

van der Heide T, van Nes EH, Geerling GW, Smolders AJP, Bouma TJ, van Katwijk M. 2007. Positive feedbacks in seagrass ecosystems: Implications for success in conservation and restoration. Ecosystems 10:1311-22.

van der Zee EM, Angelini C, Govers LL, Christianen MJ, Altieri $\mathrm{AH}$, van der Reijden KJ, Silliman BR, van de Koppel J, van der Geest M, van Gils JA, van der Veer HW, Piersma T, de Ruiter PC, Olff H, van der Heide T. 2016. How habitat-modifying organisms structure the food web of two coastal ecosystems. Proc Biol Sci 283:1-9.

Vásquez-Elizondo RM, Enríquez S. 2016. Coralline algal physiology is more adversely affected by elevated temperature than reduced $\mathrm{pH}$. Sci Rep 6:19030.

Wallace BP, DiMatteo AD, Hurley BJ, Finkbeiner EM, Bolten AB, Chaloupka MY, Hutchinson BJ, Abreu-Grobois FA, Amorocho D, Bjorndal KA, Bourjea J, Bowen BW, Duenas RB, Casale P, Choudhury BC, Costa A, Dutton PH, Fallabrino A, Girard A, Girondot M, Godfrey MH, Hamann M, LopezMendilaharsu M, Marcovaldi MA, Mortimer JA, Musick JA, Nel R, Pilcher NJ, Seminoff JA, Troeng S, Witherington B, Mast RB. 2010. Regional management units for marine turtles: a novel framework for prioritizing conservation and research across multiple scales. PLOS ONE 5:e15465.

Waycott M, Duarte CM, Carruthers TJ, Orth RJ, Dennison WC, Olyarnik S, Calladine A, Fourqurean JW, Heck KL Jr, Hughes AR, Kendrick GA, Kenworthy WJ, Short FT, Williams SL. 2009. Accelerating loss of seagrasses across the globe threatens coastal ecosystems. Proc Natl Acad Sci USA 106:12377-81.

Zieman JC, Iverson IR, Ogden JC. 1984. Herbivory effects on Thalassia testudinum leaf growth and nitrogen content. Mar Ecol Progr Ser 15:151-8. 